\title{
Research on the Impact of University-Industry Collaboration on Xi'an Construction of Innovation City
}

\author{
Fu Xinwei ${ }^{1, a}$, Duan Jie ${ }^{1, a}$, Bai Hailin ${ }^{2, b}$ \\ ${ }^{1,2}$ Northwestern Polytechnical University, Shaanxi xi 'an 710072
}

The western industrial economy research institute of Northwestern Polytechnical University, Shaanxi xi 'an 710072

${ }^{a}$ xwfu@nwpu.edu.cn ,duanjieyong@163.com , b18710707348@163.com

Keywords: university-industry collaboration, innovation city, impact

Abstract.Xi'an is one of the important innovative cities in China, and it is the new starting point of the New Silk Road Economic Zone. Therefore, this article takes Xi'an city as an example, using AHP and fuzzy comprehensive evaluation to analysis the influence of University-industry collaboration on innovation city. And this paper also makes a horizontal comparison, And the results show that the influence is basically increasing year by year, and the degree of influence is gradually improved along with the university-industry collaboration, which provides a theoretical basis for Xi'an constructing the innovation city.

\section{Introduction}

With the development of science and technology, innovation has been an inexhaustible driving force for the economic development of a country. At present, all countries in the world rely on scientific and technological innovation to enhance their scientific and technological strength. As the basic unit of an innovative country, the quality, direction and level of the construction of an innovation-oriented city will directly affect the construction of an innovation-oriented country. In the increasingly competitive trend and the shortage of resources, university-industry collaboration has become the effective use of the countries to improve the level of $\mathrm{R} \& \mathrm{D}$, transformation of mode of production, increase productivity, improve resource and promote the economic development .So this paper using AHP and fuzzy comprehensive evaluation to analysis the influence of university-industry collaboration on innovation city. The results show that the degree of influence is increasing year by year, among which the influence of cooperative innovation output is the biggest, the basic resources of cooperation is the second, and the cooperation innovation process is the weakest.

\section{Index system and model design}

\section{Index system}

According to the previous part of the theory and the above analysis of the evaluation index system, combined with the indicators used by most scholars, this paper established the following evaluation index system: Table 1 
Table 1Index system

\begin{tabular}{|c|c|c|}
\hline & Criteria layer & Index layer \\
\hline \multirow{10}{*}{$\begin{array}{l}\text { The impact of } \\
\text { University- } \\
\text { industry } \\
\text { collaboration } \\
\text { on innovation } \\
\text { city }\end{array}$} & \multirow{2}{*}{ Cooperative basic resources } & Cooperative infrastructure \\
\hline & & Other resources \\
\hline & \multirow{3}{*}{$\begin{array}{l}\text { Cooperation and innovation } \\
\text { process }\end{array}$} & Number of staff input \\
\hline & & Funds input \\
\hline & & Scope of cooperation \\
\hline & \multirow{5}{*}{ Cooperative innovation output } & Industrial innovation ability \\
\hline & & System innovation ability \\
\hline & & $\begin{array}{c}\text { Scientific and technological } \\
\text { innovation ability }\end{array}$ \\
\hline & & $\begin{array}{l}\text { Environmental innovation } \\
\text { ability }\end{array}$ \\
\hline & & Service innovation ability \\
\hline
\end{tabular}

\section{Selection of models and methods}

At present, there are SFE and DEAand so on to evaluate university-industry collaboration. The methods used in the evaluation of innovative cities are AHP, fuzzy comprehensive evaluation method, PCA, Factor Analysis and ANOVA. According to the index system selected in this paper, we first use the AHP determine the weight of each index, combined with the fuzzy comprehensive evaluation method to analyze the impact of universityindustry collaboration on the construction of innovation city in 2010-2015. Fuzzy comprehensive evaluation is not affected by the set of evaluation objects in the evaluation of objects, so it has strong applicability.

\section{Empirical Study}

\section{The determination of the weight}

Based on the existing research results, we use the most common importance scaling method:

Table 2Importance scale

\begin{tabular}{|c|c|}
\hline $\begin{array}{c}\text { Importance } \\
\text { scale }\end{array}$ & Meaning \\
\hline 1 & means that two elements are equally important \\
\hline 3 & indicates that the former is slightly more important than the \\
latter
\end{tabular}

This article uses yaahp software, visited the relevant experts and scholars, combined with the actual elements of the important degree of scale, the specific results are as follows:

Table 3Criteria layer

\begin{tabular}{|c|c|c|c|}
\hline Criteria layer & $\begin{array}{c}\text { Cooperative basic } \\
\text { resources }\end{array}$ & $\begin{array}{c}\text { Cooperation and } \\
\text { innovation process }\end{array}$ & $\begin{array}{c}\text { Cooperative } \\
\text { innovation output }\end{array}$ \\
\hline weight & 0.2 & 0.2 & 0.6 \\
\hline
\end{tabular}


Table 4Index layer

\begin{tabular}{|c|c|c|c|}
\hline Index layer & weight & Index layer & weight \\
\hline $\begin{array}{c}\text { Cooperative } \\
\text { infrastructure }\end{array}$ & 0.1 & industrial innovation ability & 0.1046 \\
\hline Other resources & 0.1 & System innovation ability & 0.0526 \\
\hline Number of staff input & 0.05 & $\begin{array}{c}\text { Scientific and technological } \\
\text { innovation ability }\end{array}$ & 0.2218 \\
\hline Funds input & 0.05 & Environmental innovation ability & 0.1176 \\
\hline Scope of cooperation & 0.1 & Service innovation ability & 0.1035 \\
\hline
\end{tabular}

Fuzzy comprehensive evaluation

First, we must determine the fuzzy comprehensive evaluation factor set: $U=$ cooperative innovation resources, cooperative innovation process, cooperative innovation output.

Then build the evaluation set: $\mathrm{V}=$ very high 60 , high 50 , higher 40 , medium 30 , low 20 , lower 10 , very low 0 , were recorded as $1,2,3,4,5,6,7$ level.

Because the original data dimension is different, so first we standardized the original data and established a single factor fuzzy matrix R:

$$
\mathrm{R}=\left[\begin{array}{ccc}
X 11 & . \mathrm{L} & X 1 \mathrm{n} \\
\mathrm{M} & \mathrm{O} & \mathrm{M} \\
X \mathrm{n} 1 & \mathrm{~L} & X n n
\end{array}\right]
$$

Every factor in each layer has weight $\mathrm{W}=\left[\begin{array}{lll}W 1 & \mathrm{~L} & W n\end{array}\right]$

Evaluation results for each factor and layer $\mathrm{B}=\mathrm{W}^{*} \mathrm{R}$, And so on we can get the final evaluation results。

\section{Results analysis and conclusions}

From the comprehensive results of Table 5, from 2010 to 2015 in Xi'an , universityindustry collaboration have high impact on the construction of innovation city overall.2010 and 2011, the degree of impact is moderate, the impact of 2012-2014 Is higher, the degree of impact in 2015 is high, and from the table can be seen the impact of production and research cooperation on the innovation city is basically increasing year by year, the overall upward trend in the existing rating of the previous level of membership is gradually increased.

In particular, from the evaluation of the basic resources of cooperation, the impact of the basic resources of the production and research cooperation on the innovation city has not changed much in the past six years. And the influence degree is relatively stable. In general, it is in a higher degree of influence. And the university-industry collaboration 's basic resources, environment and others have played an important role in constructing the innovation city.Xi'an is rich in science and technology resources, science and technology environment is good, which areconducive to the implementation of university-industry collaboration, so as to serve the construction of innovation city.

From the point of view of cooperation and innovation process, the membership degree is relatively low, which is at the lower level of evaluation grade, which shows that the overall efficiency in the process of cooperativeinnovation in Xi'an is not high, there is a large 
Table 5 Comprehensive evaluation results

\begin{tabular}{|c|c|c|c|c|c|c|c|c|}
\hline \multicolumn{8}{|c|}{ degree of membership } \\
\hline & 1 & 2 & 3 & 4 & 5 & 6 & 7 & Evaluation \\
\hline 2010 & 0.0000 & 0.0026 & 0.0963 & 0.1530 & 0.1093 & 0.0570 & 0.0218 & 4 \\
\hline 2011 & 0.0000 & 0.0020 & 0.1448 & 0.1489 & 0.0705 & 0.0621 & 0.0117 & 4 \\
\hline 2012 & 0.0000 & 0.0102 & 0.2356 & 0.0686 & 0.0605 & 0.0603 & 0.0049 & 3 \\
\hline 2013 & 0.0000 & 0.0401 & 0.2535 & 0.0138 & 0.0767 & 0.0529 & 0.0031 & 3 \\
\hline 2014 & 0.0000 & 0.1064 & 0.1893 & 0.0282 & 0.0706 & 0.0444 & 0.0011 & 3 \\
\hline 2015 & 0.0000 & 0.2366 & 0.0586 & 0.0453 & 0.0646 & 0.0350 & 0.0000 & 2 \\
\hline
\end{tabular}

Table 6 Evaluation results of three aspects

\begin{tabular}{|c|c|c|c|c|c|c|}
\hline & $\begin{array}{c}\text { cooperatio } \\
\text { n basic } \\
\text { resources }\end{array}$ & $\begin{array}{c}\text { Evaluat } \\
\text { ion }\end{array}$ & $\begin{array}{c}\text { cooperative } \\
\text { innovation } \\
\text { process }\end{array}$ & $\begin{array}{c}\text { Evaluat } \\
\text { ion }\end{array}$ & $\begin{array}{c}\text { collaborative } \\
\text { innovation } \\
\text { output }\end{array}$ & Evaluation \\
\hline 2010 & 0.0961 & 4 & 0.0925 & 6 & 0.2230 & 4 \\
\hline 2011 & 0.0855 & 3 & 0.1136 & 6 & 0.2434 & 4 \\
\hline 2012 & 0.0907 & 3 & 0.1177 & 6 & 0.3546 & 3 \\
\hline 2013 & 0.0990 & 3 & 0.1288 & 6 & 0.3786 & 3 \\
\hline 2014 & 0.1000 & 3 & 0.1248 & 6 & 0.2775 & 3 \\
\hline 2015 & 0.0972 & 3 & 0.1048 & 6 & 0.0578 & 3 \\
\hline
\end{tabular}

efficiency loss. But can be seen from Table 6, although the overall level of cooperation and innovation process is low, but in the fifth level of membership is increased, indicating that there is still a lot of room for improvement. The impact of the process on the innovation city will increasing in the future.

From the evaluation results of the cooperative innovation output, the trend of the comprehensive rating is consistent with the results. The level of the impact level has increased from grade 4 in 2010 to grade 2 in 2015, and the membership degree in 2015 has reached 0.39 , which shows that the degree of the impact of cooperative innovation output is higher than that of cooperative basic resources and cooperative innovation process on innovation city.

In general, the, university-industry collaboration will affect the construction of innovation city. The influence comes from three aspects: cooperation basic resources, cooperative innovation process, cooperative cooperation followed the weakest is cooperation and innovation process. However, To improve the innovation output, the largest power is the cooperative innovation output basic resources of cities cannot be separated from the basic resources and the process. The influence is basically increasing year by year, and the degree of influence is gradually improved with the university-industry collaboration. In fact, there are a large amount of scientific research institutes, high-tech enterprises in Xi'an, science and technology and educational resources are very rich. But from the "China's regional innovation capacity report 2015" we can know that Shaanxi Province's innovation capacity in 2015 ranked only 14, but its development potential ranked No. 6, which indicating that the level of science and technology in Shaanxi Province and economic development does not match. And Xi'an as the capital city of Shaanxi Province and the main gathering place of resources, shouldering the main tasks and responsibilities of innovation. Xi'an should unswervingly accelerate the pace of cooperation, optimize the mode of cooperation and deepen the depth of cooperation to promoting the construction of innovative cities. 


\section{ACKNOWLEDGMENT}

This work was financially supported by Xi'an Science and Technology Program Soft Science Project (NO. 2016040 / RK03 (6)) , Soft science project of Shaanxi science and technology program ( 2016KRM037 ) and Project supported by the basic scientific research of Central University ( 3102016RW001 ).

\section{References}

[1] He Xiaotong, Study on the Effect of Industry-University-Research Cooperation on Development of Innovative City [D]. University of Science and Technology of China, 2014

[2]Huo yan. Research on the Construction and Evaluation Method of Evaluation Index System of Production, Teaching and Research Cooperation [J]. Science \& Technology Progress and Policy, 2009, 26(10):125-128.

[3]Jin Furong, Luo Shougui. Researching on the Performance Evaluation Index System of Industry- University- Research Institute Collaboration [J]. SCIENTIFIC MANAGEMENT RESEARCH, 2009, 27(3):43-46

[4]Pan Yanping, Pan Xiongfeng. Evaluation and Analysis of Innovative Cities in China [J].Exploring Economic Problems,2010(7):50-54.

[5]Sun Yixiang, Huang Dangling. Construction and Empirical Study on Evaluation Index System of Innovative City [J]. Special Zone Economy, 2012(6):255-258.

[6] Yuan Changhong, Gao Jinyan ,Sun Huijuan. The Impact of Local Government Support and Regional Market Uncertainty on the Efficiency of University Technology Transfer—Evidence from Chinese "211-project”'Universities [J].R\&D, MANAGEMENT_Evidence from Chinese "211-project”Universities [J].R\&D, MANAGEMENT 2013,25(3):10-17.

[7]Xiao Guofang, Peng Sulian.Dynamic Change of University Technology Transfer performance in China Based on DEA - Malmquist Index [J]. SCIENTIFIC

MANAGEMENT RESEARCH, 2015(3):28-31. 